\title{
Activity of total alkaline phosphatase in water of the Barlinek lake of $2009-2012$
}

\section{Aktywność ogólnej fosfatazy zasadowej w wodzie jeziora Barlineckiego w okresie 2009 - 2012 rok}

\author{
Piotr Daniszewski \\ Katedra Chemii i Ochrony Środowiska Wodnego \\ Wydział Biologii \\ Uniwersytet Szczeciński \\ ul. Felczaka 3C, 71-412 Szczecin, Poland \\ E-mail address: daniszewski@univ.szczecin.pl
}

\begin{abstract}
To estimate differentiation of activity of total alkaline phosphatase in water of the Barlinek Lake, in time April - October of 2009 - 2012. Studies upon water revealed that, among the zones analyzed, upper sublittoral layer was characterized by the highest phosphatase activity. From the analysis of seasonal oscillations it follows that activity maximum for alkaline phosphatase, both in water, occurred in July 2009.
\end{abstract}

\section{Keywords:}

total alkaline phosphatase activity; phosphorus; water; Barlinek Lake

\section{STRESZCZENIE}

Badaniami objęto wodę jeziora Barlineckiego. Próbki do badań pobierano w okresie od kwietnia do października 2008 - 2012 roku. Badania dotyczące wody wykazały, że spośród analizowanych stref najwyższą aktywność fosfatazy zasadowej posiadała górna warstwa sublitoralu. Z dokonanej analizy wahań sezonowych wynika, że maksimum aktywności ogólnej fosfatazy zasadowej w wodzie występowała w badanym jeziorze w lipcu 2009 roku.

\section{Stowa kluczowe:}

aktywność ogólnej fosfatazy zasadowej, fosfor, woda, jezioro Barlineckie.

\section{WPROWADZENIE}

Nasilające się procesy związane $\mathrm{z}$ działalnością gospodarczą człowieka powodują przekształcenie środowiska wodnego a niejednokrotnie powodują jego degradację $[4,6,11]$. Stan jakości wód w zbiornikach wodnych w głównej mierze zależy od zawartości związków biogenicznych a przede wszystkim od ich dostępności biologicznej [1, 5, 9-11]. Najbardziej 
przyswajalną biologiczną formą fosforu w zbiornikach wodnych, są jony ortofosforanowe, które powstają $w$ reakcjach hydrolizy nierozpuszczalnych form fosforu $[11,14]$.

Poziom aktywności alkalicznej fosfatazy (APA) ma istotny wpływ na procesy chemiczne i biologiczne jakie zachodzą w środowisku wodnym $[7,8,13,15,16]$. APA należy do drupy wskaźników, który mówi nam o stopniu ograniczenia rozwoju biomasy w danym zbiorniku wodnym [13, 15, 17].

Celem pracy jest ocena zmian aktywności ogólnej fosfatazy alkalicznej w wodzie jeziora Barlineckiego w okresie od 2009 do 2012 roku w miesiącach od kwietnia do października.

\section{CZEŞŚĆ DOŚWIADCZALNA}

Badania przeprowadzono na jeziorze Barlineckim, które zajmuje powierzchnię 259,1 ha, posiada trzy dopływy i jeden odpływ. Otoczone jest morenowymi wzgórzami, w większości porośniętymi buczynami. Fragment brzegu zachodniego badanego jeziora przylega do łąk połączonych z polami uprawnymi. Północna i północno-wschodnia część jeziora graniczy z zabudowaniami miasta Barlinek [2, 3, 18]. Podstawowe dane morfometryczne badanego jeziora przedstawiono w tabeli $\mathrm{nr} 1$.

Tabela 1. Dane morfometryczne jeziora Barlineckiego

\begin{tabular}{|c|c|c|c|c|c|c|c|}
\hline \multirow[t]{3}{*}{ Lp. } & \multirow[t]{3}{*}{$\begin{array}{l}\text { Nazwa } \\
\text { jeziora }\end{array}$} & $\begin{array}{c}\text { Szerokość } \\
\text { geograficzna }\end{array}$ & $\begin{array}{c}\text { Długość } \\
\text { geograficzna }\end{array}$ & $\begin{array}{c}\text { Wysokość } \\
\text { n.p.m. }\end{array}$ & $\begin{array}{c}\text { Głębokość } \\
\text { maksymalna }\end{array}$ & $\begin{array}{l}\text { Głębokość } \\
\text { średnia }\end{array}$ & $\begin{array}{c}\text { Powierzchnia } \\
\text { zw. wody }\end{array}$ \\
\hline & & $\mathrm{N}$ & $\mathrm{E}$ & $\mathrm{m}$ & $\mathrm{m}$ & $\mathrm{m}$ & ha \\
\hline & & $52^{\circ} 58,9^{\prime}$ & $15^{\circ} 12,9^{\prime}$ & 57,0 & 18,0 & 7,1 & 259,1 \\
\hline \multirow[t]{3}{*}{1.} & \multirow[t]{3}{*}{ Barlineckie } & $\begin{array}{c}\text { Powierzchnia } \\
\text { wysp }\end{array}$ & Objętość & $\begin{array}{c}\text { Dlugość } \\
\text { maksymalna }\end{array}$ & $\begin{array}{c}\text { Szerokość } \\
\text { maksymalna }\end{array}$ & $\begin{array}{c}\text { Linia } \\
\text { brzegowa } \\
\text { misy } \\
\text { jeziora }\end{array}$ & $\begin{array}{c}\text { Linia } \\
\text { brzegowa } \\
\text { wysp }\end{array}$ \\
\hline & & ha & $10^{3} \mathrm{~m}^{3}$ & $\mathrm{~m}$ & $\mathrm{~m}$ & $\mathrm{~m}$ & $\mathrm{M}$ \\
\hline & & 3,7 & 18579,8 & 3770 & 2150 & 10450 & 1550 \\
\hline
\end{tabular}

Do badań próbki wody litoralnej i sublitoralnej pobierano za pomocą aparatu Ruttnera o pojemności $2 \mathrm{dm}^{3}$. Dalsze postępowanie $\mathrm{z}$ pobranymi próbkami wody było prowadzone zgodne z PN/C-04632.03. Ogólne zasady pobierania próbek do badań fizycznych, chemicznych i biologicznych. Technika pobierania próbek i PN/C-04632.04 - Ogólne zasady pobierania próbek do badań fizycznych, chemicznych i biologicznych. Utrwalanie i przechowywanie próbek.

Wodę przez dobę przechowywano $\mathrm{w}$ temperaturze $4{ }^{\circ} \mathrm{C}$. Po okresie tym określano $\mathrm{w}$ wodzie aktywność ogólnej fosfatazy zasadowej metodą Jones'a [19]. Metoda Jones'a oznaczania aktywności ogólnej fosfatazy zasadowej polega na wykryciu barwnego p-nitrofenolu powstałego $\mathrm{z}$ fosforanu $\mathrm{p}$-nitrofenolu rozpuszczonego w buforze $(0,1 \mathrm{M}$ Tris- $\mathrm{HCl}$ o $\mathrm{pH} 8,5)$ [19]. Badania prowadzone były w okresie od kwietnia do października 2008 roku. Analizy wykonywano raz w miesiącu $\mathrm{w}$ trzech powtórzeniach. Przedstawione $\mathrm{w}$ pracy wyniki stanowią średnią $\mathrm{z}$ tych powtórzeń. 
Rozmieszczenie punktów badawczych na jeziorze Barlineckim przedstawiono na schemacie nr 1 .

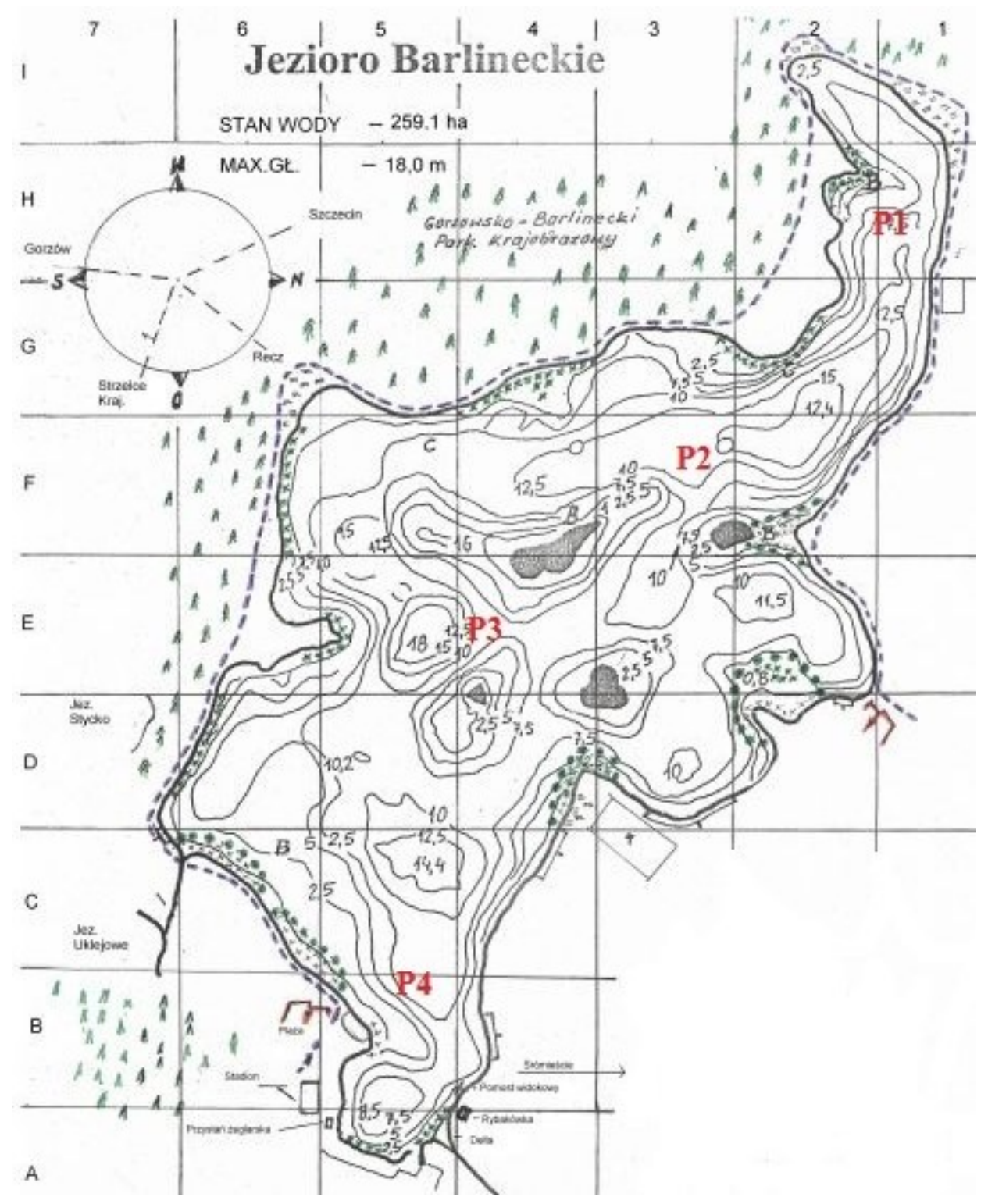

Schemat 1. Rozmieszczenie punktów badawczych na jeziorze Barlineckim [18].

\section{DYSKUSJA WYNIKÓW}

Wyniki badań aktywności ogólnej fosfatazy zasadowej w wodach jeziora Barlineckiego zostały przedstawione w tabeli 2 . 
Tabela 2. Aktywność ogólnej fosfatazy zasadowej w wodzie $\left(\mathrm{nmol} \mathrm{PO}_{4} \cdot \mathrm{dm}^{-3} \cdot \mathrm{h}^{-1}\right)$ [średnie z czterech punktów pomiarowych]

\begin{tabular}{|c|c|c|c|}
\hline Lp. & Terminy analiz & Litoral & Sublitoral \\
\hline \multicolumn{2}{|r|}{2009} & $1 \mathrm{~m}$ & $4 \mathrm{~m}$ \\
\hline 1. & Kwiecień & 272,4 & 167,2 \\
\hline 2. & Maj & 386,3 & 251,5 \\
\hline 3. & Czerwiec & 395,6 & 316,2 \\
\hline 4. & Lipiec & 584,2 & 478,3 \\
\hline 5. & Sierpień & 513,7 & 481,8 \\
\hline 6. & Wrzesień & 286,4 & 343,6 \\
\hline 7. & Październik & 110,2 & 163,2 \\
\hline \multicolumn{2}{|r|}{2010} & $1 \mathrm{~m}$ & $4 \mathrm{~m}$ \\
\hline 1. & Kwiecień & 260,2 & 183,6 \\
\hline 2. & Maj & 325,4 & 264,1 \\
\hline 3. & Czerwiec & 390,5 & 328,3 \\
\hline 4. & Lipiec & 526,8 & 462,6 \\
\hline 5. & Sierpień & 521,3 & 439,2 \\
\hline 6. & Wrzesień & 324,6 & 361,4 \\
\hline 7. & Październik & 93,7 & 128,4 \\
\hline \multicolumn{2}{|r|}{2011} & $1 \mathrm{~m}$ & $4 \mathrm{~m}$ \\
\hline 1. & Kwiecień & 241,9 & 176,2 \\
\hline 2. & Maj & 359,7 & 247,2 \\
\hline 3. & Czerwiec & 389,4 & 334,1 \\
\hline 4. & Lipiec & 563,8 & 471,4 \\
\hline 5. & Sierpień & 547,7 & 443,1 \\
\hline 6. & Wrzesień & 292,8 & 332,7 \\
\hline 7. & Październik & 98,3 & 146,2 \\
\hline \multicolumn{4}{|c|}{2012} \\
\hline 1. & Kwiecień & 250,4 & 170,4 \\
\hline 2. & Maj & 337,2 & 243,9 \\
\hline 3. & Czerwiec & 380,4 & 308,4 \\
\hline 4. & Lipiec & 540,3 & 463,6 \\
\hline 5. & Sierpień & 549,2 & 437,2 \\
\hline 6. & Wrzesień & 283,7 & 319,4 \\
\hline 7. & Październik & 102,5 & 151,6 \\
\hline
\end{tabular}


Powyższe wyniki wskazują, że aktywność ogólnej fosfatazy zasadowej w wodzie jeziora Barlineckiego kształtowała się w okresie prowadzonych badań od 93,7 do 584,2 $\mathrm{nmol}_{\mathrm{PO}_{4}} \cdot \mathrm{dm}^{-3}$ $\cdot \mathrm{h}^{-1}$. W litoralu poziom badanego wskaźnika wynosił od 93,7 do 584,2 $\mathrm{nmol} \mathrm{PO}_{4} \cdot \mathrm{dm}^{-3} \cdot \mathrm{h}^{-1}$, a

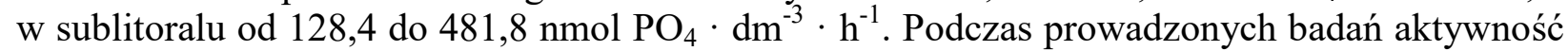
ogólnej fosfatazy zasadowej, wody ocenianego jeziora, podlegały wahaniom w poszczególnych latach oraz miesiącach. Wiosną (w maju) i w lecie (przede wszystkim w lipcu) stwierdzono podwyższony poziom ocenianego wskaźnika w litoralu jak i sublitoralu. W toni wodnej maksimum ogólnej aktywności fosfatazy zasadowej wystąpiło w lipcu 2009 roku w strefie litoralu i wynosił 584,2 $\mathrm{nmol} \mathrm{PO}_{4} \cdot \mathrm{dm}^{-3} \cdot \mathrm{h}^{-1}$. Natomiast najmniejszy poziom badanego wskaźnika wystąpił w październiku 2010 roku.

\section{WNIOSKI}

1. Aktywność ogólnej fosfatazy zasadowej w wodzie jeziora Barlineckiego była najwyższa w warstwie sublitoralu.

2. Aktywność ogólnej fosfatazy zasadowej w wodzie badanego jeziora podlegała wahaniom sezonowym w całym okresie badawczym $2009-2012$.

3. W toni wodnej najwyższą wartość ogólnej aktywności fosfatazy zasadowej wystąpił w lipcu 2009 roku w strefie litoralu i wynosił $584,2 \mathrm{nmol} \mathrm{PO}_{4} \cdot \mathrm{dm}^{-3} \cdot \mathrm{h}^{-1}$.

4. Najmniejszy poziom ogólnej aktywności fosfatazy zasadowej wystąpił w październiku 2010 roku - i wyniósł w strefie litoralu $93,7 \mathrm{nmol} \mathrm{PO}_{4} \cdot \mathrm{dm}^{-3} \cdot \mathrm{h}^{-1}$, natomiast w strefie sublitoralu wyniósł $128,4 \mathrm{nmol} \mathrm{PO}_{4} \cdot \mathrm{dm}^{-3} \cdot \mathrm{h}^{-1}$.

\section{Polskie Normy}

PN/C-04632.03. Ogólne zasady pobierania próbek do badań fizycznych, chemicznych i biologicznych. Technika pobierania próbek.

PN/C-04632.04. Ogólne zasady pobierania próbek do badań fizycznych, chemicznych i biologicznych. Utrwalanie i przechowywanie próbek.

PN/C-06504. Przygotowanie roztworów buforowych.

\section{References}

[1] Barik S. K., Purushothaman C. S., Mohanty A. N., Aquacult. Res. 32 (2001) 819-832.

[2] Brodzińska B., Janczak J., Kowalik A., Sziwa R., Atlas jezior Polski. T. 1. Poznań 1996

[3] Brodzińska B., Janczak J., Kowalik A., Sziwa R., Atlas jezior Polski. T. 2. Poznań 1997

[4] Dojlido J.R., Chemia wód powierzchniowych. Wydawnictwo Ekonomia i Środowisko 1995.

[5] Elbanowska H., Zerbe J., Siepak J., Fizyczno-chemiczne badania wód, Wydawnictwo Naukowe PWN 1999, s. 232.

[6] Hermanowicz W., Dojlido J., Dożańska W., Koziorowski B., Zerbe J., Fizyczno-chemiczne badanie wody i ścieków, Arkady, Warszawa 1999.

[7] Berman T., Limnol. and Oceanogr. XV (5), (1970) 663-674. 
[8] Chróst R. J., Siuda W., Halemejko G. Z., Arch. Hydrobiol. Suppl. 70(1) (1984) 1-32.

[9] Daniszewski P., International Letters of Chemistry, Physics and Astronomy 1 (2012) 6-12.

[10] Daniszewski P., International Letters of Chemistry, Physics and Astronomy 1 (2012) 13-16

[11] Koc A., Skwierawski A,. Fosfor w wodach obszarów rolniczych, Prace Naukowe Akademi Ekonomicznej we Wrocławiu, 1017 (2004) 168.

[12] Marcinkiewicz W.. Barlineckie Jezioro, Wyd. Instytut Rybactwa Śródlądowego, Olsztyn 1963.

[13] Siuda W., A review. Pol. Arch. Hydrobiol. 31 (1984) 207-233.

[14] Siuda W., Post. Mikrobiol. 40(2) (2001) 187-217.

[15] Smith R. E. H., Kalff J., Can.J.Fish Aquat Sci. 38 (1981) 1425.

[16] Jansson M., Olssonh., Pettersson K., Hydrobiol. 170 (1988)157-175.

[17] Forsberg C., Eutrophication of the Baltic Sea. Fyris-Tryck AB, Uppsala, (1993) 5-6.

[18] Marcinkiewicz W., Barlineckie Jezioro, Wyd. Instytut Rybactwa Śródlądowego, Olsztyn 1963.

[19] Jones J. G., J. Ecol., 60 (1972) 777-791. 